\title{
Kan man opstille adfærdsregler for offentlig debat?
}

\author{
Af Christian Koch
}

Denne artikel slår til lyd for at vi har brug for adferdsregler for offentlig debat. De skal ikke bestå $i$ begrensninger afytringsfriheden og selvcensur, ikke i nedfaldede bestemmelser eller organer til at håndhave dem-men $i$ skerpet refleksion, bevidsthed og diskussion om hvad der er rimelig adferd $i$ offentlig debat. Iser blandt journalister, medie- og kommunikationsforskere og politiske kommentatorer kunne denne skerpede bevidsthed vare ønskelig; den kunne f.eks. få dem til at vare mere kritisk agtpågivende når politikere og andre personer med indflydelse offentligt diskuterer og besvarer sporgsmål.

Bag denne programerklæring ligger en vigtig præmis: nemlig at offentlig debat faktisk har formål (et eller flere) - dvs. at den tjener fællesskabets og samfundets interesser (f.eks. ved at den er vigtig for demokratiets bedst mulige funktion). Denne præmis står i modsætning til den opfattelse at offentlig debat kun skal anskues som de enkelte politiske aktørers manøvrer til at fremme deres egen magt og interessemaksimering.

I politologi og politisk filosofi var det indtil ca. 1990 en dominerende opfattelse af politisk debat at den netop havde denne karakter. Politik er ifølge denne opfattelse stridende aktørers kamp om fordelingen af samfundskagen og om at præge samfundet mest muligt i den retning disse aktører hver for sig ønsker; dette er så at sige ideen om det rationelt agerende økonomiske menneske, forstørret op til at gælde for alle områder i det politiske liv. Den retning i økonomi og andre samfundsvidenskaber der hedder "rational choice theory", er ofte drivkraften under politisk tænkning af denne art. Det er en central opfattelse hos den at aktører i samfundet, både individer og stridende interessegrupper, vælger deres standpunkter ud fra stabile præferencer og rationelle overvejelser om hvad der tjener disse præferencer bedst. I dette lys får politisk debat en meget begrænset rolle, for folks præferencer er jo netop stabile; de kan højst ændre deres overvejelser om hvad der tjener deres præferencer bedst, men de ændrer ikke selve præferencerne eller prioriteringen af dem. En opfattelse der ofte går hånd i hånd med denne, er at alle bidrag til of- fentlig debat derfor blot er agitation, en rent strategisk verbal ageren for at udstrække egne interesser maksimalt, primært ved at få nogle vælgere til at tro at agitatorens politik tjener disse vælgeres forudgivne præferencer. Anskuet på denne måde har debat ikke, og kan ikke have, nogen reel og gavnlig funktion for fællesskabet der er værd at bekymre sig om, og ingen central plads i en teori om hvad demokrati er.

Men inspireret ikke mindst af Habermas' politiske og kommunikationsteoretiske tænkning i 80'erne og af John Rawls' samfundsfilosofi begyndte flere og flere politiske tænkere fra ca. 1990 at tale om det deliberative demokrati - hvormed de mente at offentlig debat i form af deliberation (der på latin egentlig betyder at veje for og imod, som på en købmandsvægt, en libra) faktisk var eller burde være en central faktor i demokrati. I Danmark havde vi allerede i 1940'erne en art foregribelse af modsætningen mellem de to slags tænkning om demokrati i form af debatten mellem Hal Koch (1945) og Alf Ross (1946), med Hal Koch som repræsentant for det "deliberative" standpunkt. Ifølge deliberative demokrati-tænkere er debat om politiske valg og handlinger afgørende for demokratiets kvalitet, ja måske for at det overhovedet kan kaldes demokrati. Et argument er at deliberativ debat har tendens til at give bedre afgørelser, et andet er at borgernes deltagelse i deliberativ debat om samfundets styre er en værdi i sig selv. Under alle omstændigheder er tilhængere af deliberativt demokrati enige om at deliberativ debat kan få nogle af debattens til- 
hørere (og måske endda nogle af dens deltagere) til at skifte mening om hvilke mål der skal prioriteres i samfundet. Heroverfor vil de politologer der snarere ser den politiske proces som analog med markedsmekanismerne, mene at samfundets medlemmer har de ønsker, interesser og prioriteringer som de har. Politisk debat vil da højst være en art kappestrid om hvem der bedst kan indynde sig hos vælgerne som leverandører af det vælgerne på forhånd ønsker og prioriterer. Set på den måde făr deliberativ debat ikke nogen vigtig funktion for samfundet, men højst for de kræfter der gerne vil opnå og bevare samfundsmagten.

Demokrati-teorier der indebærer at deliberativ debat har en funktion og værdi for samfundet som sådant, må som konsekvens heraf interessere sig for hvad der principielt gør en deliberativ debat god. Alle slags ting der har en vigtig funktion, kan jo tænkes at udføre denne funktion godt eller dårligt. Hvornår gør den så det ene, hvornår det andet?

En anden konsekvens er at der er brug for kritiske iagttagere som, ud fra den slags principielle overvejelser, observerer og evaluerer konkret offentlig debat. For mange tilhængere af deliberativt demokrati siden Habermas har det været et ideal at debat i princippet skulle føre frem til konsensus. Dette er en tankegang der minder om spillereglerne på fællesmøder i Christiania og lignende alternative samfund: Alle skal være enige, før en beslutning kan træffes og debatten afsluttes. Men der er også tænkere der hylder deliberativt demokrati uden at tro på muligheden (eller ønskeligheden) af at føre enhver debat frem imod konsensus. Hvis sådanne samfundstænkere skulle gøre rede for debattens funktion, ville de ikke acceptere at tilvejebringelsen af konsensus er den ultimative funktion. De vil så skulle finde et andet svar på hvorfor vi skal have debat; hvis det ikke er meningen at vi skal blive enige alle sammen, hvorfor så bruge en masse tid og resurser på offentlig debat i stedet for bare at stemme om tingene og få fordelt magt og goder til de stridende interessegrupper alt efter deres styrke?

Jeg vil i denne artikel argumentere for den samfundsmæssige værdi af deliberativ debat, men ikke ud fra at den nødvendigvis fører imod konsensus - hverken faktisk, ideelt eller tendentielt. Mit overordnede svar på hvad der så er debattens funktion, er at den skal tiene til at give beslutningstagere og valgere/borgere et bedre grundlag for at treffe et valg om vigtige beshutninger, men at borgerne meget vel kan ende med at velge forskelligt. Debat skal til for at give fornuften mere plads, men der eksisterer også noget der hedder "reasonable disagreement" - med et udtryk der blev skabt og diskuteret bl.a. af John Rawls (1989, 1993). Debat skal - tilspidset sagt - til netop for at vi i sidste ende kan nå frem til en uenighed der er fornuftig frem for ufornuftig.

Men jeg vil gerne have lov til nu at forlade den almene begrebsdiskussion og i stedet gå induktivt frem. Det vil ske ved at jeg fremlægger nogle eksempler på fænomener i autentisk politisk debat som bevidstgør grænsen mellem det jeg mener er god og legitim debat, og det jeg mener er kritisabelt, og som nogen derfor bør slå ned på. Eksemplerne er et udvalg af den samling jeg har opbygget gennem længere tid. Jeg mener at autentiske eksempler på debatadfærd som ligger på grænsen for det der opleves som legitimt, eller over denne grænse, er et afgørende redskab til refleksion; det er min opfattelse at sprog- og argumentationsteorier der er startet med en teoretisk grundopfattelse af hvad der f.eks. er sprogets væsen eller "gyldig" argumentation, alt for ofte er endt i noget virkelighedsfjernt. Diverse sprogvidenskabelige retninger anerkender at grammatiske og andre regler for sproget eksisterer som intuitioner hos indfødte sprogbrugere, $\mathrm{og}$ at det er sprogbeskrivelsens opgave at eksplicitere disse intuitioner systematisk; tilsvarende kan man antage at en opfattelse af hvad der er rimelig sproglig debatadfærd, findes i en intuitiv, passiv form hos sprogbrugere. Er det tilfældet, er det oplagt at nøje betragtning af intuitioner i forbindelse med konkrete eksempler er et vigtigt redskab når denne "rimelighed" skal ekspliciteres.

\section{Eksempel 1 er her.}

(1) der er direktører, chefredaktører, partiformænd, succes-forfattere, tidligere udenrigsministre - you name them - som er mere optaget af 'flerkulturel mangfoldighed' end af [at] stå fast på vores værdier. Det er folk, der opfordrer til 'samtale' og 'forståelse'. At dialogen skal foregå med islamister, der støtter håndsafhugninger og stening af kvinder, anfægter ikke disse folk. For dem er 'dialogen' hellig - uanset hvilke formørkede typer man samtaler med.

Det er nyttigt (og ganske uhyggeligt) at vide, at der findes danskere, som ser sådan på verden. Nyttigt at vide, at stærke og indflydelsesrige kræfter her i landet mener, at vi burde 
have undskyldt for nogle harmløse tegninger, blot fordi nogle truende islamistiske regimer kræver det.

(Fra Henrik Qvortrup, "Mange tak til Fyllands-Posten", metroXpress 9.3.2006)

Hvad ser vi her? Nogle standpunkter kritiseres, f.eks. det standpunkt at vi "burde have undskyldt" for de tegninger. Men hvem er "vi"? Det synes at være "dette land". Og hvem har dette kritisable standpunkt? Det fremgår at bl.a. "tidligere udenrigsministre" har det. Dem er der en lille håndfuld af i Danmark, f.eks. Uffe Ellemann-Jensen. Men mig bekendt har ingen tidligere danske udenrigsministre fremført det standpunkt at vi "burde have undskyldt".

Eksempel 2 er Karen Jespersens “øde ø”. I 2000 fandt politiet at visse asylsøgere, især fra den tidligere østblok, begik mange tyverier og sendte tyvekosterne retur til hjemlandet.

(2) "Man er nødt til at gøre noget håndfast. Ellers risikerer vi, at fænomenet vokser. Hvis de har begået en lovovertrædelse af en vis grovhed, så undersøger vi nu, om de kan blive placeret på et særligt center på et øde beliggende område. Man kan f.eks. tage en ubeboet ø," siger Karen Jespersen og nævner Middelgrundsfortet ud for København som en mulighed. (Berlingske Tidende 25.8.2000)

Karen Jespersens udtalelse blev et stort tema som blev gentaget og kommenteret i lang tid. Forfatteren Stig Dalager skrev f.eks. i Politiken, 24.11.2001 - mere end et år senere, og umiddelbart efter det valg der bragte Anders Fogh Rasmussens regering til magten:

(3) Når en dansk indenrigsminister noget tid før valgkampen lufter en straffeekspeditionslignende forestilling om at lejrplacere særligt besværlige personer med indvandrerbaggrund til observation på en øde ø, så er der fra officielt politisk hold givet grønt lys for de nok så berømte indre svinehunde.

Og Thomas Bredsdorff skrev i en tv-anmeldelse, Politiken, 28.11.2001:
(4) Karen Jespersens skændsel er ikke så meget det, hun udrettede, som det, hun sagde hun ville udrette, men ikke kunne. Hun ophidsede den ene halvdel af befolkningen ved sin uhumske retorik om øde øer til kriminelle indvandrere, den anden halvdel ved ikke at levere øerne, når det kom til stykket.

I disse to citater ser vi samme manøvre som før hos Qvortrup, bare med modsat politisk fortegn. Se på Karen Jespersens oprindelige udtalelse og dens kontekst, derunder formålet med den omtalte idé, nemlig at begrænse tyverier begået af bestemte asylansøgere, som er grebet i kriminalitet, og som formentlig vil blive hjemsendt. Se så på gengivelser af udtalelsen som Dalagers "straffeekspeditionslignende forestilling om at lejrplacere særligt besvarlige personer med indvandrerbaggrund til observation på en øde ø". Hver af de fem kursiverede formuleringer repræsenterer små, men vigtige forskydninger af hvad der er sagt og ment. Læseren af denne artikel kan selv som en øvelse prøve at beskrive hvori forskydningerne består. Bredsdorff kan derpå referere til Karen Jespersens "uhumske retorik om øde øer" (nu i flertal) som om det at hun står for en sådan retorik, var et velkendt faktum.

At tillægge folk standpunkter de aldrig har fremsat og sikkert ikke deler, kaldes at "opstille en stråmand". Piet Hein kalder det "At dutte folk en mening på / hvis vanvid alle kan forstå". Forfatteren og musikskribenten Mogens Wenzel Andreasen var fejlagtigt sat på som medunderskriver til et indlæg fra Dansk Forfatterforening om indvandrerdebattens dårlige "tone". Han skrev i et læserbrev:

(5) jeg ønsker at holde på min ret til at tage afstand fra kvindeundertrykkelse, æresdrab, dødstrusler mod forfattere og henrettelse af filminstruktører på åben gade uden af den grund at få skudt i skoene, at jeg bidrager til et underlødigt debatniveau. Jeg ønsker heller ikke at blive slået i hartkorn med en hykler som Carsten Jensen, som det ene øjeblik fromt prædiker om ordentlig debatmoral for derpå at omtale en folkevalgt politiker som 'Dronning af skraldebøtterne" eller noget i den retning. Hvad Carsten Jensen end måtte mene om Pia Kjærsgård, har hun ret til samme behandling i debatten som de voldsmænd, mordere, kvindeundertrykkere etc., Carsten Jensen har så travlt med at tage i forsvar. 
At tillægge Carsten Jensen det standpunkt at forsvare voldsmænd, mordere eller kvindeundertrykkere er klart at "dutte folk en mening på hvis vanvid alle kan forstå". Man kan tilføje at ingen andre end Wenzel Andreasen selv i de sidste 10 år synes at have brugt vendingen "Dronning af skraldebøtterne" (hvis databasen Infomedia står til troende).

Men én ting er at man som her forvansker modpartens standpunkter. En anden ting, der er beslægtet, er hvordan man fremstiller modpartens argumenter for vedkommendes standpunkter (forudsat modparten altså har de standpunkter man angriber, hvad der ofte ikke er tilfældet). Kun af og til får man så tillige gengivelse af de argumenter som modparten har brugt, eller som de har i tankerne.

I eksempel 6 ser vi en anden manøvre som også tit bruges over for modpartens kritiske modargumenter: en subtil fordrejning af deres argument. En læserbrevsskribent, Jørgen Bülow Hansen, kritiserer den 28.7.04 i Politiken den radikale udlændingeordfører Elsebeth Gerner Nielsen fordi hun har skrevet forord til en pjece der viser hvordan man kan omgå loven som forhindrer sammenføring med en udenlandsk ægtefælle før det 24. år:

(6) $\mathrm{Nu}$ vil mange selvfølgelig sige, at der er så mange, der bryder loven, men at Det Radikale Venstres udlændingeordfører, Elsebeth Gerner Nielsen, har medvirket direkte med et forord i denne pjece - det er uforståeligt! Fru Nielsens deltagelse vidner ikke om den store forståelse for det lovgivende demokrati.

Hvad er kritikpunktet her? Det er som før ikke gjort helt eksplicit, men det fremgår dog klart af ordlyden at hvad der specifikt forarger læserbrevsskribenten, er et folketingsmedlems medvirken til at omgå den lov som Folketinget har vedtaget. Her er så folketingsmedlemmets "svar" (d. 1.8.04):

(7) Det burde være logik for enhver, at politikere ikke skal bøje sig, fordi et flertal har en anden mening. Jørgen Bülow Hansen (28.7.) mener imidlertid, at jeg ikke kan tillade mig at skrive forord til en pjece, fordi pjecens indhold er i strid med flertallets holdning. Jeg er selvfølgelig lodret uenig med JBH.

Men JBH har jo ikke sagt at politikeren ikke må støtte noget som er imod "flertallets holdning". Han har derimod kritiseret det at hun - tilmed som folketingsmedlem - efter hans mening medvirker til at omgå en af Folketingets love. Her ser vi altså igen det som Piet Hein kalder "at dutte folk en mening på hvis vanvid alle kan forstå". Men vi har her at gøre med en særlig underart af "stråmands"-manøvren; det der forvanskes her, er ikke selve modpartens standpunkt, det er derimod hans argument for sit standpunkt.

Og igen er det klart at forsyndelsen medvirker til dårlig oplysning af sagen, ja til direkte og aktiv formørkelse af den. Gerner Nielsen mener vel ikke selv at hun omgår eller undergraver det lovgivende demokrati; hvorfor kommer hun så ikke med sine grunde til at hun ikke mener noget sådant? Formentlig fordi det ville være en svær og subtil argumentation at føre frem. I stedet for et sådant relevant bidrag til sagens oplysning vælger hun derfor at lade som om modparten har ytret det skøre standpunkt at man ikke må være uenig med flertallet.

Der er i hvert fald to måder hvorpå man kan lave en stråmand ud af modpartens argument. Den manøvre som eksemplet viser, kan kaldes den tumpede stråmand, for det argument som politikeren her tillægger sin modpart, er tumpet. Alt imens glemmer vi så måske det mere plausible argument som modparten faktisk har fremført. Publikum, vælgerne og læserne, der måske ønsker at tage stilling til den danske udlændingelovgivning ved at overveje argumenterne for og imod, bliver dermed atter snydt.

Den anden type argument-stråmand kan kaldes den tandløse stråmand - man leverer her en gengivelse af modpartens argument der er ukontroversiel, fordi argumentet har fået fjernet de tænder der virkelig kunne have bidt.

Det leverede Anders Fogh Rasmussen en subtil demonstration af (eksempel 8) ved et pressemøde den 21. februar 2006. Han var blevet anklaget for at han havde mistolket et brev fra 11 muslimske landes ambassadører. Den påståede mistolkning, og den følgende afvisning af deres ønske om et møde, var ifølge kritikere en medvirkende årsag til at "Muhammed-krisen" eskalerede. Fogh svarede bl.a.:

(8) Så er der nogen, der har sagt, at man kunne have oversat brevet på en anden måde. (Gengivet efter Politiken 22. februar 2006.)

Dette udsagn forvansker på afgørende vis kritikernes argument mod Foghs handlemåde. For 
argumentet var jo ikke at brevet kunne oversættes anderledes, men at det skulle oversættes anderledes; Fogh havde altså ifølge dette argument læst forkert, dvs. ageret på inkompetent måde. Det var bare ikke det han svarede på.

Man ser igen i disse to eksempler hvordan en forskydning som umiddelbart kan ligne en ren nuanceforskel, gør at parterne, muligvis fuldt bevidst, taler helt forbi hinanden.

MF Helga Moos (V) skrev i Politiken 20.4.2004 om et forsøg hun havde set i Mexico med GMOmajs der kunne tåle tørke. Det lovede godt for verdens sultproblemer hvis vi tillod disse planter, mente hun.

Det fik Enhedslistens Keld Albrechtsen på banen (26.4.04). Han havde set de samme to forsøgsplanter som Helga Moos på den samme studietur for politikere. Han skrev:

(11) Ærlig talt, jeg havde ikke fantasi til at forestille mig, at medlemmer af Folketingets Miljøudvalg kunne drage konklusioner på så løst et grundlag.

Her søger han bevidst at fremstille modstanderen som idiot - en standardmanøvre i offentlig debat. Naturligvis bygger Moos ikke sit forsvar for GMO'er alene på to planter - hun bruger dem som et illustrativt eksempel, ikke som videnskabelig dokumentation. Senere nævner Albrechtsen så en række punkter der rejser tvivl om at GMO'er er et entydigt gode. Det er fint - men han får ikke kommenteret et eneste af de argumenter Moos faktisk gav i sit indlæg for at de kan brødføde den fattige verden.

Ikke at kommentere modpartens gode argumenter er standard i politisk debat. I stedet anvender man manøvrerne fortegning og fortielse. Albrechtsen gjorde i sit indlæg begge dele. Og diskussionen gik videre med at Moos på sin side gjorde ganske det samme ved Albrechtsens indlæg. Taberne blev de læsere der måtte have ønsket at afveje argumenterne for og imod GMO'er.

At tillægge modstanderen ekstreme synspunkter som de ikke har givet udtryk for, eller forvanske og mistolke deres udsagn i den retning, er beslægtet med at tillægge modparten hemmelige planer og motiver.

Det ser vi i eksempel 11. Da Udvalgene Vedrørende Videnskabelig Uredelighed (UVVU) i januar 2003 kritiserede Bjørn Lomborg for "objektiv uredelighed", kom der debat i onsdagsspørgetiden i Folketinget om hans egnethed som direktør for Institut for Miljøvurdering. Her sagde Statsministeren bl.a.:

(11) Det, fru Pernille Blach Hansen, det, hr. Jørn Jespersen, det, hr. Keld Albrechtsen er ude efter, er overhovedet ikke spørgsmålet om videnskabelig redelighed eller uredelighed. Det er jo almindelig heksejagt på Bjørn Lomborg. Sådan har det været, lige siden instituttet blev oprettet, for venstrefløjen ønsker ikke, at der bliver en kritisk debat om dansk miljøpolitik. Venstrefløjen ønsker ikke, at der foretages en kritisk vurdering af, hvordan vi får mest mulig miljø for pengene. Og det er det, det her handler om.

Så dækker man sig ind under alt muligt formelt sniksnak. Men det, det handler om, er, at man ikke ønsker instituttet.

Allerede inden da havde regeringens folk været ude i medierne med denne teori om motiverne til kritikken, bl.a. skrev Venstres miljøordfører Eyvind Vesselbo sådan her i Fyllands-Posten d. 13. januar:

(14) Udvalgene Vedrørende Videnskabelig Uredelighed (UVVU) har med sin afgørelse i forbindelse med Bjørn Lomborgs bog indledt næste fase i den useriøse politiske kamp mod Institut for Miljøvurdering.

Der er stærke kræfter, som arbejder ihærdigt på at få lukket instituttet, fordi de frygter, at seriøse økonomiske beregninger af miljøindsatsen vil kunne rykke bevillingerne på miljøområdet fra et felt til et andet.

På denne måde vil de, der sidder på flæsket i dag, kunne miste både penge og indflydelse.

Det er derfor, kampen mod miljøinstituttet lige fra starten har været så hård og kompromisløs.

Her tillægges kritikerne ikke alene skjulte motiver til deres kritik, der tales også om en regulær sammensværgelse af kræfter med fælles motiver - en konspiration af både politiske modstandere og forskere, derunder Udvalgene Vedrørende Videnskabelig Uredelighed.

I filosofiske lærebøger om argumentation, kritisk tænkning o.l. siger man gerne at det er en "fallacy" at tale om personen og dennes motiver frem 
for om "sagen". Det er "ad hominem" argumentation. ${ }^{1}$ Men vi ved jo fra vidneudsagn i retssager og fra f.eks. den historiske kildekritik at motiverne til hvad folk siger, kan være særdeles relevante at tage i betragtning. Så er der egentlig noget galt med Foghs og Vesselbos argumentation her? Ja, men det gale er egentlig ikke at de angriber kritikernes påståede motiver, selv om angrebet rigtignok er ret spekulativt; det gale er igen at man ikke svarer på selve kritikken mod Lomborg, og de heftige angreb på kritikernes skjulte og konspiratoriske motiver kan let ses som en manøvre der skal bortlede opmærksomheden fra denne kritik og fra det manglende svar på den.

Igen har forsyndelsen altså at gøre med at man så at sige svigter sin oplysningspligt. Ligesom Albrechtsen og Moos forsømmer Fogh og Vesselbo at hjælpe tilhørerne, som i princippet er det danske folk, til at kunne vurdere hvor tungtvejende kritikken mod Lomborg er.

"Fallacies" er som sagt et nøglebegreb i den traditionelle tilgang til læren om god og dårlig argumentation. Den traditionelle definition af fallacies, med baggrund i Aristoteles, er at "fallacies" er folgeslutninger som synes at være gyldige, men som ikke er det. I politisk argumentation forekommer der imidlertid sjældent logisk "gyldige" slutninger. Det ligger i politiske sagers natur. Politik er at vælge eller fravælge en handling. Handlinger er ikke udsagn og har ikke egenskaberne "sandhed" eller "usandhed".

Derfor nytter det ikke at efterstræbe en norm eller et sæt adfærdsregler for politisk argumentation der sætter tvingende argumentation op som mål - lige så lidt som vi kan kræve eller forvente konsensus i politisk debat. Det er fordi politik handler om handlinger vi overvejer, ikke om påstande som vi fremsætter.

En handling er nemlig hverken sand eller falsk. Skal 24-års-reglen afskaffes? Skal alle danskere stå i et DNA-register? Skal homoseksuelle ægteskaber tillades? Skal vi have lavere skatter? Skal vi nedsætte sodavandsafgiften? At tale om "sandhed" om den art spørgsmål er filosofisk vås. Her er der ikke tale om påstande, men om valg, vilje og "forsæt" og som Aristoteles slår fast i sin Eudemiske etik, "gælder sandt og falsk ikke om Forsættet" (1226a; 1955, 54). Én part kan have det politiske standpunkt, forsæt eller mål at skatterne skal ned, en anden at de skal op. Prædikaterne sand eller falsk kan ikke med mening appliceres på nogen af disse standpunkter.
Af samme grund gælder at man i politiske diskussioner kun kan søge folks tilslutning - ikke fremtvinge den.

Men lever vi mennesker så bare i hver sin egen lille private værdi-boble? Kan vi så ikke diskutere politiske og moralske afgørelser fornuftigt med hinanden? Svaret er: Jo, vi kan, og vi skal. Bare fordi jeg ikke kan bevise at folk skal tilslutte sig det jeg synes, kan jeg godt prøve at vinde deres tilslutning alligevel.

Personer med forskellig prioritering af værdier kan altså debattere så meget de vil, og det skal de, og de kan gøre det med fuld overholdelse af alle gode adfærdsregler - men de bliver ikke nødvendigvis enige. Det er legitimt at enhver gerne vil have sine værdibegreber og prioriteringer til at vinde fremme. Vi kan opstille adfærdsregler for sådan en debat, men vi kan ikke kræve at den fører til konsensus.

Hvad vi heller ikke kan, selv om Jürgen Habermas $(1981 ; 1972)$ argumenterer for det, er at sige at folk ikke må argumentere "strategisk". Det er at man taler for at opnå en virkning, f.eks. at overbevise andre. Det er forkert, mener Habermas, man skal tale sammen alene for at kommunikere og opnå forståelse, og så vil vi ideelt set opnå konsensus i kraft af det som Habermas med en ofte citeret vending kalder "det bedre arguments ejendommelige tvangfrie tvang".

Indledningsvis argumenterede jeg for at der er brug for den art regler, i hvert fald hvis man tror på deliberativt demokrati og mener at offentlig debat har en funktion for fællesskabet. Eksemplerne vi har set, viser nogle af de fænomener som kalder på kritik. Meget af det som politikere og andre offentlige debattører tillader sig, spreder vildledning og mørke over de emner vi skal træffe beslutninger om, og undergraver betingelserne for at tale sammen.

Men hvad kan vi så forlange af dem, og hvad kan vi ikke forlange? Her er et bud på nogle regler. Det centrale er for det første at offentlig debat skal tjene til at belyse de relevante argumenter i en sag. Man kan bruge et udtryk fra Aristoteles og sige at debat skal gøre det muligt for os tilhørere og vælgere at overskue "de mulige overbevisende momenter i ethvert givet stof" (1983, 33; 1355b). For det andet er det centralt at debat skal hjælpe hver enkelt tilhører med at sammenligne argumenterne for og imod med hinanden. For der vil jo gerne være argumenter både for og imod, og afvejnin- 
gen af dem er nødvendig. Det er fordi vi debatterer vore forsæt, og om dem "gælder sandt og falsk ikke". Man kan ganske vist i høj grad debattere afvejningen af argumenterne, men da der mangler en objektiv, logisk målestok, kan debatten ikke bevise hvilken afvejning der er den "sande"; tilhørerne må lytte til debatten, blive klogere af den og så hver for sig vælge hvad de synes vejer tungest. Derfor er det så vigtigt at debattørerne giver reelle svar på hinandens argumenter, dvs. giver begrundede bud på hvordan de skal afvejes. Det skal de gøre for tilhørernes skyld, ikke for at debattørerne selv skal finde en konsensus, for det kan man ikke regne med. Principielt er det legitimt at de taler for at vinde tilslutning til deres synsmåde, ikke for at blive enige. Kort sagt:

Vi kan ikke forlange at debattører:

- skal bevise at deres politik er "sandheden" med tvingende logiske slutninger

- ikke må kommunikere "strategisk", dvs. for at vinde vores tilslutning

- skal nå frem til konsensus

Vi kan forlange at debattører:

- anerkender at en modstander legitimt kan synes noget andet end de selv

- angiver eksplicit og præcist hvilket standpunkt de forsvarer eller kritiserer

- fortrinsvis kritiserer standpunkter som nogen har

- hvis de mener at nogen har de kritiserede standpunkter, da angiver eksplicit og præcist hvem

- ikke kritiserer nogen for standpunkter som de ikke er sikker på at de pågældende har, eller for udtalelser som de ikke er sikker på at de pågældende har fremsat

- fremfører deres grunde eksplicit, dvs. ikke blot tager dem som underforståede eller forudsatte

- begrunder deres standpunkter med grunde, dvs. med henvisninger til de fordele som de mener de vil give, eller andre konkrete grunde

- lytter til modargumenter

- svarer på modargumenter sådan som de fremføres af modparten, dvs. at de gør én af disse to ting:

$$
\begin{aligned}
& \text { enten: - 1) anerkender modargumen- } \\
& \text { tets sandhed og/eller relevans } \\
& \text { - og i tilfælde heraf: at de giver } \\
& \text { grunde til at argumenterne for } \\
& \text { standpunktet til trods derfor har }
\end{aligned}
$$

større vægt end det/de fremførte modargumenter

eller: - 2) kritiserer modargumentets sandhed og/ eller relevans, dvs. giver grunde til at modargumentetikke ersandtog/eller relevant - kun angriber en modstanders person hvis det punkt angrebet handler om, har relevans for den diskuterede sag, og kun hvis debattøren tillige overholder de ovenstående krav om at svare på modpartens argumenter

Denne kodeks ville sætte iagttagere, f.eks. journalister eller universitetsforskere, i stand til mere præcist og med større tyngde at slå ned på de uskikke og forseelser vi har set eksempler på. I denne kodeks opfattes samtalen ikke som en platonisk dialog, men som en trialog - en proces der finder sted til glæde for tredjepart, vælgerne, som ikke selv naivt antages at være deltagere i et stort direkte demokrati der i vore dages samfund er uigennemførligt. Reglerne er formuleret med det grundlæggende hensyn at hvad der end siges af debattørerne, skal være til nytte for vælgerne. De skal tjene til sagens oplysning og ikke til dens mørklægning, og dermed skal de hjælpe vælgerne til at træffe mere kvalificerede valg.

\section{Litteraturhenvisninger}

Aristoteles. 1955. Vejen til Livslykken. Aristoteles' eudemiske Etik. Oversat med indledning og noter af Poul Helms. København: Nyt Nordisk Forlag Arnold Busck.

Aristoteles. 1983. Retorik. Oversat og med introduktion af Thure Hastrup. København 1983: Museum Tusculanums Forlag.

Berlin, Isaiah 2005. Den ideale straben og andre essays. København: Gyldendal. Orig. "The Pursuit of the Ideal" i The Crooked Timber of Humanity: Chapters in the History of Human Ideas. London: Fontana Press 1988.

Finnis, John. 1998. "Commensuration and public reason", i Ruth Chang (ed.): Incommensurability, Incomparability, and Practical Reason. Cambridge, Mass.: Harvard University Press, s. 215-233.

Grice, H.P. 1975. "Logic and conversation", i Cole, P. and Morgan, J. (eds.): Syntax and semantics, vol 3. New York: Academic Press.

Habermas, Jürgen. 1972. "Wahrheitstheorien", i Vorstudien und Ergänzungen zur Theorie des kommunikativen Handelns. Frankfurt/M.: Suhrkamp, s. 127-183.

Habermas, Jürgen. 1981. Die Theorie des kommunikativen Handelns, Band I: Handlungsrationalität und gesellschaftliche Rationalisierung. Franfurt: Suhrkamp, 1981.

Hitchcock, David. 2006. "The Pragma-Dialectical Analy- 
sis of the Ad Hominem Fallacy"; i Peter Houtlosser \& Agnès van Rees (eds.): Considering Pragma-Dialectics. A Festschrift for Frans H. van Eemeren on the Occasion of his 60th Birthday. Mahwah, New Jersey: Lawrence Erlbaum Associates, s. 109-119.

Koch, Hal. 1945. Hvad er demokrati? København: Gyldendal.

Kock, Christian. 2003. "Multidimensionality and Non-Deductiveness in Deliberative Argumentation", i Frans H. van Eemeren, J. Anthony Blair, Charles A. Willard \& A. Francisca Snoeck Henkemans (eds.): Anyone Who Has a View: Theoretical Contributions to the Study of Argumentation. Dordrecht: Kluwer Academic Publishers, s. 157-171.

Kock, Christian. 2006a. "Journalisten som udspørger og ordstyrer - bag om offentlige debattørers snyd og manipulationer", i Flemming Svith (ed.): At opdage verden. Research - Fra akademikere til journalister. Århus: Forlaget Ajour, s. 105-125.

Kock, Christian. 2006b. "Multiple Warrants in Practical Reasoning", i David Hitchcock \& Bart Verheij (eds.): Arguing on the Toulmin Model: New Essays on Argument Analysis and Evaluation. Dordrecht: Springer, s. 247-259.

Kock, Christian. 2007a. "Norms of Legitimate Dissensus", i Informal Logic 27, s. 179-196.

Kock, Christian. 2007b. "Dialectical Obligations in Political Debate", i Informal Logic 27, s. 233-247.

Larmore, Charles. 1996. The Morals of Modernity. Cambridge: Cambridge University Press.

Rawls, John. 1989. "The domain of the political and overlapping consensus", i New York University Law Review 64, 233-255.

Rawls, John. 1993. Political Liberalism. New York: Columbia University Press.

Raz, Joseph. 1998. "Incommensurability and Agency", i Ruth Chang (ed.): Incommensurability, Incomparability, and Practical Reason. Cambridge, Mass.: Harvard University Press, s. 110-128.

Raz, Joseph. 2000. Engaging Reason: On the Theory of Value and Action. Oxford: Oxford University Press.

Ross, Alf. 1946. Hvorfor demokrati? København: Munksgaard.

Walton, Douglas. 1998. Ad Hominem Arguments. Tuscaloosa: University of Alabama Press, 1998

Walton, Douglas. 2000. "Case Study of the Use of a Circumstantial Ad Hominem in Political Argumentation", i Philosophy and Rhetoric 33, s. 101-115.
Walton, Douglas. 2001. "Searching for the Roots of the Circumstantial Ad Hominem", i Argumentation 15, s. $207-$ 221.

Walton, Douglas. 2004. "Argumentation Schemes and Historical Origins of the Circumstantial Ad Hominen Argument", i Argumentation 18, s. 359-368.

Woods, John. 2007. "Lightening Up on the Ad Hominem", i Informal Logic 27, s. 109-134.

\section{Note}

1. Læren om fallacies har været et filosofisk emneområde siden Aristoteles' Om sofistiske gendrivelser, med bl.a. John Locke og Stuart Mill som bidragydere. Hamblin (1970) leverede en stærk kritik af fallacy-læren for dens usystematiske rodekasse-tilgang til emnet. Canadierne Douglas Walton og John Woods tog i en serie artikler omkr. 1980 fat på at gøre noget ved dette med den såkaldte "Woods-Walton Approach" til fallacies, men Walton udviklede i 80'erne sin egen tilgang til emnet under inspiration af den hollandske "pragma-dialektiske" skole inden for argumentationsteori. Denne anser fallacies for at være sproghandlinger i argumentation som modvirker samtalens formål: at nå til enighed. Walton opererer dog med et spektrum af forskellige samtaletyper, hver med sit formål. Ud fra denne orientering har han skrevet en serie bøger og artikler om alle de traditionelle "fallacy"-typer; her anskues deres "fejlagtighed" som noget relativt, afhængigt af samtaletyper, kontekst, m.v. Om "ad hominem", se bl.a. Walton (1998, 2000, 2001, 2004). "Ad hominem" anses altså ikke altid for en argumentationsfejl. Det er blevet almindeligt at inddele "ad hominem" argumenter i tre hovedtyper: 1) at tale nedsættende om modparten ("abusive ad hominem"); 2) at påpege omstændigheder der gør modparten utroværdig, f.eks. manglende uvildighed ("circumstantial ad hominem"); 3) at påpege at modparten selv kan kritiseres for det han angriber ("tu quoque"). Senere behandlinger af emnet når frem til at "ad hominem" som sådan slet ikke er en argumentationsfejl; se Hitchcock (2006), Woods (2007). 